

\section{Learning, Entrepreneurship And Innovation Orientations In Turkish Family-Owned Firms}

\author{
Erkut Altindag \\ Cemal Zehir \\ A.Zafer Acar
}

\section{Introduction}

Strategic management is the conduct of drafting, implementing and evaluating crossfunctional decisions that will enable an organization to achieve its long-term objectives. It is a level of managerial activity under setting goals and over tactics including some special tools like strategic orientations. These orientations involve both strategy formation called content and also strategy implementation called process (David, 1989; Chaffee, 1985). During the last decades, strategic orientations in family owned firms have received increased attention among scholars. The heart of the strategic management process is to achieve the performance outcomes that allow firms, including family-influenced firms, to be competitive over time (Habbershon, et al., 2003; Pieper \& Klein, 2007). Family businesses significantly affect to economy and the social life of a nation. The typical family business has been characterized as an organizational controlled and usually managed by multiple family members In general, management structure in the family business will determined by the top level manager. Usually at least two generations of family are found in corporate governance. In the definition of the family company; spouse, siblings, mother / father and child may enter the partnership of the management board or support the capital as a shareholder (Shanker \& Astrachan 1996; Lunsber 1999). Recent researches indicates that companies achieve their aims easily which are in family firm structure. Family firms often have concentrated ownership and / or voting rights that might enhance performance (Miller et.al., 2007). Family businesses may offer particularly appealing circumstances for studying certain kinds of organizational phenomena (Chrisman et al., 2003). The aim of this article is to develop a model of family business that accounts for the unique characteristics of family business, specify the diversity of orientation forms, and addresses the dynamics among family-owned business firm performance. It is hoped that this special research will contribute to filling this gap.

\section{LITERATURE REVIEW}

\section{Family-Owned Firms}

The literature on family business is wideranging and it is difficult to find consensus on the exact definition of a family firm. However, the typical family business has been characterized as an organization controlled and usually managed by multiple family members (Shanker \& Astrachan, 1996; Lansberg, 1999), often from multiple generations (Anderson \& Reeb, 2003; Gomez-Mejia et al., in press). Family firms can be viewed as a contextual hybrid - a unique combination of two sets of rules, values, and expectations: the family's and the business's (Flemons \& Cole, 1992; Gersick et al, 1997;). Family firms share certain characteristics that render them unique in terms of patterns of ownership, governance, and succession (Chrisman et al 1999; Steier, 2003).

A family business is a business in which one or more members of one or more families have a significant ownership interest and significant commitments toward the business' overall wellbeing. In some countries, many of the largest publicly listed firms are family-owned. A firm is said to be family-owned if a person is the 
controlling shareholder; that is, a person (rather than a state, corporation, management trust, or mutual fund) can garner enough shares to assure at least $20 \%$ of the voting rights and the highest percentage of voting rights in comparison to other shareholders (Chakrabarty, 2009).

For instance, owner-families share the desire for ownership control and the continuity of family involvement in the firm. To fully appreciate these special characteristics, it is crucial to focus on family firms where the family is likely to have considerable impact on entrepreneurial activities. We therefore define family firms as firms where one family group controls the company through a clear majority of the ordinary voting shares, the family is represented on the management team, and the leading representative of the family perceives the business to be a family firm (Naldi, et.al. ,2007). Most of the research projects studying goals in family firms compare the goals of these types of firms to those of non-family firms in order to detect significant differences. Results in relation to this subject are mixed. In family firms, goals related to family roles tend to be far more important than the traditional firm-value maximization goal (Sharma et al., 1997). Among those important family roles are survival, financial independence, family harmony and family employment (Trostel \& Nichols, 1982; Donckels \& Frolich, 1991; Westhead, 1997). Moreover, family firms are described as being more risk-averse and less growth-oriented. They focus less on technology, creativity and innovation (Donckels \& Frölich, 1991).

However, most of the family firm managers believe that they are operating in a hostile external environment (Westhead, 1997).

In the literature and organizational context, innovation may be linked to performance and growth through improvements in efficiency, productivity, quality, competitive positioning, market share, etc. All organizations can innovate, including for example hospitals, universities, and local governments. A convenient definition of innovation from an organizational perspective is given by Luecke and Katz (2003), who wrote: "Innovation is generally understood as the successful introduction of a new thing or method; innovation is the embodiment, combination, or synthesis of knowledge in original, relevant, valued new products, processes, or services."

Discussion of the innovation philosophy generally refers to issues such as new products, technology, and discontinuous improvement, while discussion of the marketing philosophy generally concerns matters such as customer service, customer satisfaction and customer focus. The tendency to see these philosophies as mutually exclusive is reinforced by the specialization of academics and consultants in one or the other area. Some scholars, however, have paid attention to the need to integrate technology and market (Berthon et al, 2004).

An innovation-oriented knowledge structure is a set of organization-wide shared beliefs and understandings that guide and direct "all organizational strategies and actions, including those embedded in the formal and informal systems, behaviors, competencies, and processes of the firm" (Simpson et al., 2006). Most prior innovation research has focused on factors that affect innovations, primarily rate, speed and benefits. More recent research has examined innovation as a system-based, firm-wide orientation toward innovation. Along with this broader perspective comes a need for understanding outcomes of the orientation, both positive and negative. The innovation literature to date has largely relied on a handful of specific, readily calculated outcomes of innovation, with few studies examining the link between a more comprehensive innovation orientation and its organizational effects (Totterdell et al., 2002). Though no known studies have empirically examined innovation orientation effects on consumers, Schlegelmilch et al. (2003) make a compelling argument that a strategic innovation will yield 'proactive value creation' and Totterdell et al. 
(2002) find a relationship between novelty and greater perceived benefits to customers.

With another orientation entrepreneurial activities in family firms do involve taking risks, but to a lesser extent than in non-family firms. If family firms generally are characterized by less internal and external formal monitoring, risk taking in family firms is likely to mean that these family firms make decision that are less bias on closely calculated risks; less grounded in a systematic, unbiased way; and with less incorporation of outsiders' perspectives and opinions (Schulze et al, 2001; Naldi et al, 2007). In many global markets, speed of technological change is rapid. Especially family firm-based companies have to adopt this turbulent environment as an organic organization. Innovation-oriented firm focuses on developing key organizational competencies in resource allocation, technology, employees, operations and markets. Most prior innovation research has focused on factors that affect innovations, primarily rate, speed and benefits (Simpson, et al., 2006).

Organizations that are competent learners are called "learning organizations". Garvin (1993) defined a learning organization as "an organization skilled at creating, acquiring, and transferring knowledge, and at modifying its behavior to reflect new knowledge and insights". Most scholars' view organizational learning as a process, a cognitive enterprise, that unfolds over time, but they differ on other important matters. Some believe that behavioral change is required for learning others insist that new ways of thinking are enough Learning organization, an organization's implicit or explicit understanding of how things are done is often referred to as its theory in use. Organizational learning occurs when members of the organization act as learning agents for the organization, responding to changes in the internal and external environments of the organization by detecting and correcting errors in organizational theory in use, and embedding the results of their inquiry in private images and shared maps of organization. There has been a new perspective for significantly increasing organizational learning by providing a greater understanding of related and required concepts of change, learning, collaborative work systems, teams, synergy and authentic teams, co-mentoring relationships and learning teams, and their implementation in organizations. Learning orientation has four sub-dimensions in own structure. Team orientation is about the group members and their success as working together. All members should complement each other and must serve the same purpose. System orientation means all departments and employees create an effective system with the high level of rationalizing. Learning sub-dimension shows the degree of adapting to new circumstances and reaching success. At last, shared memory is the key element of organizational culture.

All employees have a common history and their values are similar. These all sub-dimensions are about the increasing of firm efficiency when to be quickly adapted to the environment is necessary. Having the knowledge to better link resources to customer needs and increasing the pace of change within the organization (Pedler et al., 1997; Baker et al, 2007).

Each strategic orientation has various effects on growth and profitability performance in family based businesses. In various studies, the positive way strong relationships were found between the active return rate, growth in sales, new product success, increasing market share and profitability performance indicators (Narver \& Slater, 1990). In this research, family business' financial and growth performance are tried to analyze by managers or chiefs' perspectives. Firm performance is connected to effective use of performance measures in the family firm.

\section{METHOD}

\section{Conceptual Framework}

The purpose of this empirical study is to evaluate the effects of strategic orientations levels 
on firm performance in family firms. In this connection, the hypothesis which we use in our study is improved by scientific literature and created a model that explains the causes of orientations over firm's qualitative and quantitative performance.

If the family owned firms restructure their organizations with strategic orientations; firms have the potential to gain superior financial and growth performance. We expect a direct relationship between strategic orientations and firm's performance; with support of the modern literature, these hypotheses are expanded :

H1: There is a positive, significant and direct relationship between innovation orientation and business performance

$\mathrm{H} 2$ : There is a positive, significant and direct relationship between entrepreneurship orientation and business performance

H3: There is a positive, significant and direct relationship between learning orientation and business performance

\section{Sampling and Data Collecting}

The aim of this study is to provide an explanation for the contradictory evidence in the literature regarding the performance of Turkish family-owned firms. For this purpose, it's evaluated the effects of strategic orientations levels on firm performance in family firms. In order to empirically investigate the hypothesis of the study, familybased firms are chosen in Istanbul area. To collect the data some tools as e-mail, letter and face to face interviews are used. Minimum two members from each firm was claimed to participate the research survey.

Total of 280 questionnaires have returned among over 130 firms. The descriptive statistics of the respondents are shown in Table 1. All items were measured on a seven point Likert-type scale where $1=$ strongly disagree and $7=$ strongly agree Data is evaluated by SPSS 16.0 statistical program. The relationships between the all variables are tested using factor, reliability, correlation and regression analyses.

\begin{tabular}{|c|c|c|c|c|c|}
\hline Gender & Frequency & Percent & Hierarchical Status & Frequeracy & Percent \\
\hline Sale & 210 & 75 & Iop Level Man / Onmer & 38 & 13,6 \\
\hline Femole & 70 & 25 & Middle Level Man & 96 & 34.3 \\
\hline Total & 280 & 100 & Botsom Level Managrt & 146 & 52.1 \\
\hline & & & Total & 280 & 100 \\
\hline Education & Frequency & Percent & Teaure & Frequescy & Percent \\
\hline Primary School & 7 & 2.5 & $1-5$ years & 177 & 63.2 \\
\hline High School & 39 & 13,9 & $6-10$ years & 70 & 25 \\
\hline $\begin{array}{l}\text { Vocational } \\
\text { School }\end{array}$ & 19 & 6,8 & $11-20$ years & $2 ?$ & 9,6 \\
\hline Grodicate & 144 & 51.4 & $20+$ yeas & 6 & 2,1 \\
\hline Master / FaD & $\pi$ & 25,3 & & & \\
\hline
\end{tabular}

Measures

All constructs were measured with existed scales from previous literature. The first of these scales is the entrepreneurship orientation. This instrument designed by Li et al. (2007), was used to measure the construct of entrepreneurship orientation level of the firms. Second one is innovation orientation. This instrument is modified by Hurley \& Hult (2004) and Gatignon \& Xuereb (1997). The other scale is learning orientation used by Hult et al in 2003. At last, firm's performance scales in the questionnaire are taken from recent management studies (Baker \& Sinkula, 1999; Lynch et al, 2000; Zahra et al., 2002). These items were measured on a seven point Likert-type scale where $1=$ strongly disagree and $7=$ strongly agree. All questions are tested for linguistic and meaning errors and it's controlled by Brislin's (1970) backtranslate method for the translation of questionnaires.

Scale Validity and Reliability In our study, all items and components are tested by comprehensive reliability analyses. As a beginning, it's analyzed the alpha reliability test (Croanbach); all the scale reliability coefficient has been determined a satisfactory level such that $\square=, 953$; this value is quite over the recommended 0.70 threshold (Nunnally 1978; Nunnally, and Bernstein 1994). The variables those exist in the scale are tested individually; some items are removed before the analyses process (e5 from entrepreneurship orientation, i7, i9 and i10 from innovation orientation, p3 and p9 from performance). Later on this process, the cumulative reliability coefficient 
value increased to $\square=, 964$. This level is higher than the critical threshold value $(0.700)$ that generally accepted in the literature. The scale structure that was obtained with factor analysis was evaluated with the Kolmogorov-Smirnov test, and it was seen that $t$ values of all of the variables were at the sufficient level for our sample that prove that the distribution of the data is statistically normal. At next step, it's examined the "corrected inter-item correlations" and "squared multiple correlations" in the item analysis stage. It was found that, except two items all of the resulting values were 0.500 and above. In pursuit of reliability and correlation analyze, it is determined the factor structures by basic component analyze. During this process, Entrepreneurship and innovation orientations constituted only one component. Learning orientation disintegrated as four components (team orientation, system orientation, learning orientation and shared memory orientation).

Table-2: Factor Analyses

\begin{tabular}{|c|c|c|c|}
\hline Variables & $\begin{array}{c}\text { Number of } \\
\text { components }\end{array}$ & $\square$ & Total Explained Variance \\
\hline Entrepreneurship Orientation & 1 & 0,864 & $\% 71,301$ \\
\hline Innovation Orientation & 1 & 0,910 & $\% 65,696$ \\
\hline Learning Orientation & 4 & 0,967 & $\% 81,779$ \\
\hline Business Performance & 2 & 0,930 & $\% 73,219$ \\
\hline
\end{tabular}

\section{Test of the Research Questions}

After testing reliability and the factorial structure, correlation analysis of the research questions was begun with the purpose of examining the mutual relationship among the factors considered in our research model. It was determined that the four independent latent variables had mutually positive relationships $(\square<0.001)$ with each other and with business performance components (see Table 3).

Table -3: Correlation Matrix

\begin{tabular}{|c|c|c|c|c|c|c|c|c|c|c|}
\hline & Mean & St.D. & 1 & 2 & 3 & 4 & 5 & 6 & 7 & 8 \\
\hline Entrepreneur & 4,823 & 1,483 & 1,000 & & & & & & & \\
\hline Innovation & 5,157 & 1,328 &, $756^{* *}$ & 1,000 & & & & & & \\
\hline Team & 5,248 & 1,546 &, $394^{* *}$ &, $418^{* *}$ & 1,000 & & & & & \\
System & 5,471 & 1,313 &, $421^{* *}$ &, $483^{* *}$ &, $718^{* *}$ & 1,000 & & & & \\
\hline Learning & 5,306 & 1,462 &, $347^{* *}$ &, $332^{* *}$ &, $693^{* *}$ &, $687^{* *}$ & 1,000 & & & \\
\hline Shared Memo. & 5,008 & 1,586 &, $348^{* *}$ &, $382^{* *}$ &, $759^{* *}$ &, $668^{* *}$ &, $729^{* *}$ & 1,000 & & \\
Financial P. & 4,563 & 1,116 &, $310^{* *}$ &, $318^{* *}$ &, 082 &, 102 &, 026 &, 015 & 1,000 & \\
\hline Growth P. & 4,598 & 1,386 &, $443^{* *}$ &, $464^{* *}$ &, $144^{*}$ &, $167^{* *}$ &, 106 &, 087 &, $693^{* *}$ & 1,000 \\
\hline
\end{tabular}

$$
\mathrm{p}^{*}<0,05 ; \mathrm{p}^{* *}<0,01
$$

As shown on the correlation table, all sub-factors of the learning orientation have not a strength mutual relationship between firm performances. Especially the learning and shared memory sub-factors of the learning orientation have no significant effect on business performance of the firm. The Pearson correlation coefficient indicates the strength of a linear relationship between two variables, but its value generally does not completely characterize their relationship. Because of this, after reveal of the mutual relations of examining factors in the model, the linear relationship was tested with regression analysis. According to the analyses' results (see Table 4):

Learning, Entrepreneurship And Innovation Orientations In Turkish Family-Owned Firms 
Entrepreneurship ( $\square: 0,182$; ) and innovation ( $\square: 0,225)$ orientations directly, positively and significantly affect to the firm's financial (a) performance. So, H1a and H2a hypothesis are supported. (R2: ,130; F:6,768). Consistent with our hypotheses, this construct that includes these orientations is also valid and relevant in the important organizational context of family owned firms.

Entrepreneurship ( $\square: 0,231)$ and innovation ( $\square: 0,341$ ) orientations directly, positively and significantly affect to the firm's growth (b) performance. H1b and H2b hypothesis are supported. (R2: ,248; F:14,950)

Learning orientation significantly impact reversely on financial and growth performance. This situation is not valuable for our empirical study. Because of these findings, an H3a and H3b hypotheses are not supported.

Table -4: The Effects of Strategic Orientations on Business Performance

\begin{tabular}{|c|c|c|c|c|c|c|}
\hline & \multicolumn{3}{|c|}{ Model 1} & \multicolumn{3}{|c|}{ Model 2} \\
\hline & $\square$ & $t$ & $P$ & $\square$ & $T$ & $p$ \\
\hline Entrepre. &, 182 & 2,080 &, 038 &, 231 & 2,831 &, 005 \\
\hline Innovation &, 225 & 2,488 &, 013 &, 341 & 4,043 &, 000 \\
\hline Team &, 053 &, 539 &, 591 &, 023 &, 239 &, 804 \\
\hline System &, 008 &, 088 &, 930 &,- 035 &,- 411 &, 682 \\
\hline Learning &,- 048 &,- 527 &, 598 &, 014 &, 166 &, 868 \\
\hline \multirow[t]{2}{*}{ Shared Memories } &,- 145 & $-1,485$ & 139 &,- 128 & $-1,411$ &, 159 \\
\hline & \multicolumn{3}{|c|}{$\begin{array}{l}\text { Dependent variable: Financial performance } \\
\qquad R^{2}=, 130 F=6,768 ; p<0,001\end{array}$} & \multicolumn{3}{|c|}{$\begin{array}{l}\text { Dependent variable: Growth performance } \\
\qquad R^{2}=, 248 F=14,950 ; p<0,001\end{array}$} \\
\hline
\end{tabular}

Depending to the results given in Table 4, we deduced that both entrepreneurship and innovation orientations have statistically significant direct positive effects on business performance with all dimensions of the firm. On the other hand, there is no significant prove of the affects of learning orientation with all sub dimensions on the firm performance. There is no correlation between learning orientations and firm performance. In other words, the raising the values of independent variables in the innovation and entrepreneurship make the firm performance increased. There is a linear relationship between the entrepreneurship and performance; innovation and performance. As a further invention, the high correlation between this two independent variables shows that this two orientations using together in the family owned firms. We also support these findings:

Although the learning orientation does not affect firm performance, two sub factors of learning orientations have a positive and significant effect on entrepreneurship and innovation orientation. Hence this situation, learning orientation may affect the family-owned firm's growth and financial performance indirectly. Especially the sub factors named team and system orientation positively and significantly affect the entrepreneurship and innovation orientations which exist in learning orientation's structure model. These findings also appropriate with the correlation analysis results. recorded as an unexpected discovery in our research (see table 5). 
Table -5: The Effects Learning Orientation's sub factors on Entrepreneurship and Innovation Orientations

\begin{tabular}{|c|c|c|c|c|c|c|}
\hline & \multicolumn{3}{|c|}{ Model 3} & \multicolumn{3}{|c|}{ Model 4} \\
\hline $\begin{array}{c}\text { Sub } \\
\text { Dimensions }\end{array}$ & $\beta$ & $t$ & $p$ & $\beta$ & $t$ & $p$ \\
\hline Team &, 162 & 2,011 &, 034 &, 138 & 2,488 &, 013 \\
\hline System & ,266 & 3,136 &, 002 & ,392 & 4,784 &, 000 \\
\hline Learning &, 037 & ,429 & 668 &,- 095 & $-1,121$ &, 263 \\
\hline \multirow[t]{2}{*}{$\begin{array}{c}\text { Shared } \\
\text { Memories }\end{array}$} &, 020 &, 217 &, 828 &, 085 & ,941 &, 347 \\
\hline & \multicolumn{3}{|c|}{$\begin{array}{l}\text { Dependent variable: Entrepreneurship Orient. } \\
\qquad R^{2}=, 196 ; F=16,701 ; p<0,001\end{array}$} & \multicolumn{3}{|c|}{$\begin{array}{c}\text { Dependent variable: Innovation Orient } \\
R^{2}=, 248 ; F=22,561 ; p<0,001\end{array}$} \\
\hline
\end{tabular}

With this findings we can assume that employers of all levels (bottom to top) including stakeholders are they key facts for implementing innovation and entrepreneurship orientations. As a sub factor of learning orientation, system orientation is about the connection between all departments inside a firm. It's related to added value of every employers and strategic business unit; system orientation is closely influenced into the entrepreneurship and innovation orientation. Another sub factor is team orientation explains the system as a firm that enhancing individual growth as well as organizational growth. There is a strong believe to enhance coordination and communications between function departments.

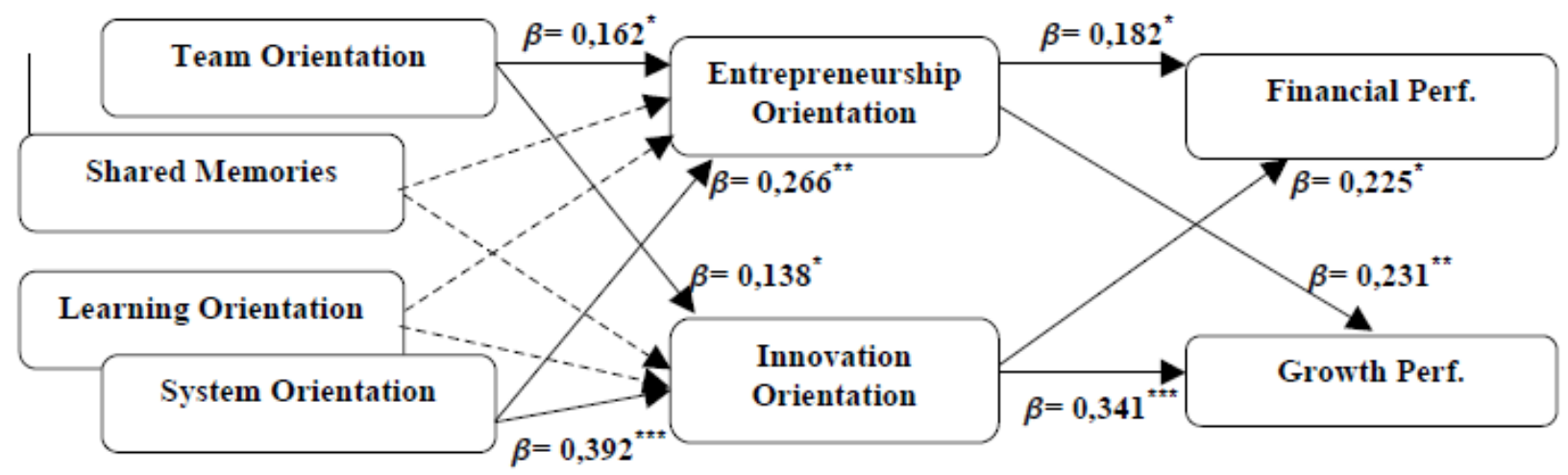

Figure-1: The final model of the research

\section{IV.DISCUSSION}

\section{Conclusion}

This study focuses on the effect of strategic orientations on the family based firms' performance. Our research findings provide some valuable notions. The results of our empirical study show that some strategic orientations including innovation and entrepreneurship are implementing by Turkish family firms to achieve sustainablecompetitive advantage in turbulent markets. Effects of strategic orientations evolve over time and that it is the implementation of the strategy which is truly important, rather than the classification of the strategic type. It may be possible for other strategic types to improve performance by altering their strategy profiles to be 
more aggressive, more focused or time-consuming when implementing decisions. In this research, entrepreneurship and innovation orientations are connected to firm's performance's elements as profitability, revenues before taxes, growth rate in the market, employee number, new customers, innovative products or services and financial success. For instance, the success of innovative output affects to firm's competitive advantage in a turbulent market. The organizational learning is a key determinant of manufacturing without errors and low costs. Several managers change their management comprehension for creating a customer focused, market-driven strategies. Our finding shows that the firms which use any strategic orientation are capable to be the better performers inmany markets. That's what the reason of some family firms are successful. In the strategic management literature, as well as there are some researches who claim all strategic orientations effect positively on firm performance $\square$ (Hult vd., 2003; Olson et al., 2004), there are some dissidents (Manu and Sriram, 1996; Noble etal., 2002). Findings show that there is a meaningful and positive relationship between the innovation, entrepreneurship and firm performance. This finding can be evaluated as Turkish family firms follow and integrate the modern management theories and global trends into their structure. These orientations have got same character; the high correlation between these two variables may be the evidence of it. They are both being used for competitive advantages for Turkish family owned firms. The managers emphasize the innovation and entrepreneurship orientations to protect firm's position and possess stronger composition than rivals. Our results suggest that innovation orientation is also shown the faith to new products and services that interests of companies; entrepreneurship orientation leads various abilities including fast fight back and leading the new services and products in the market. The results indicate that the association between strategic orientation and performance varies depending on the type of orientation used. Managers need to be able to assess the orientation of their organizations in this regard, and to consider carefully whether their assessment of the situation was that intended, and whether it is appropriate to the business environment (Berthon, et.al., 2004). our study suggests that an entrepreneurship orientation is beneficial for improvement of new product development activities in a transitional economy; top managers of firms should incline toward choosing entrepreneurship as their main strategic orientation. As a general thing, our results call into question the usefulness of learning orientations. There's no significant finding that these orientations with all dimensions affect to firm's performance. By the way, learning orientations' some subdimensions effect the innovation and entrepreneurship orientations and their implications for internal environment of the company and making a definitive system. This is also indirectly affects performance. Once again, our empirical study is an important step in validating the relationship between strategic orientations and firm performance. Also it provides that Turkish family firms are tend to use modern management theories in their structural organization. In the findings in replications of our research support our findings, the message to the family firm managers is clear. In the competitive market, family firms must evaluate their performance and choose a suitable strategic orientation to achieve competitive advantage strategy. It's a new way to achieve to the success for the family owned firms. The using of these orientations helps to increase family-owned business' profitability and growth rate in turbulent markets. This conclusion has implications for managers and management professors. We recommend the following:

The examined orientations must be used together as a combination of success. Using the innovation andentrepreneurship orientations compatible with each other can be considered as a proof of this.

It's recommended that to specify the role of learning orientations which don't directly effect 
on to otherorientations to the academicians working on this issue. As a special finding, we found a strong relationship both system and team orientation affect the entrepreneurship and innovation orientation. A model which is designed to evaluate the sub dimensions of learning orientations' effects on other strategic orientations can be useful for future researches.

The managers can use both the innovation and entrepreneurship orientations to improve efficiency of the family-owned firms. New product success rate, degree of product differentiation, first to market with new applications, sales growth and customer satisfaction are some criterions to reach the firm's vision by using strategic orientations (Lee and Tsai, 2005).

Family-owned firm managers should examine the other orientations that including customer, relationship and market as a new technique to achieve sustainable performance.

\section{Limitations and future research directions}

Our empirical study has several limitations that should be kept in mind. Family firms differ on a range of dimensions and it is possible that different types of family firms show different patterns in terms of all orientations. Our data consisted of Turkish family firms and inference to other countries should be made with caution. National culture and tradition may influence especially entrepreneurship and learning orientation, which has implications for the generalization of our findings. In contrast, responses from more individuals within the firms would have given a more complete picture of the firm's situation and behavior. Also our contributions tofamily business research open up possibilities for future researches. 


\section{References}

1. Baker W.E. and Sinkula, J.M. 1999. The synergistic effect of market orientation and learning orientation on organizational performance. Journal of the Academy of Marketing Science, Vol. 27(4), 411-427.

2. Baker W.E. and Sinkula, J.M 2007. Does market orientation facilitate balanced inno vation programs? An organizational learning perspective. The Journal of Product Innovation Management, Vol.24, 316-334.

3. Berthon, P., Hulbert, J.M. and Pitt, L. 2004. Innovation or customer orientation? An empirical investigation. European Journal of Marketing, Vol.38 (9-10), 1065-1090.

4. Brislin, R. W. 1970. Back-translation for cross-cultural research. Journal of Cross-Cultural Psychology Vol.1, 185-216.

5. Celuch, K.G., Kasouf, C.J. and Peruvemba, V. 2002. The effects of perceived market and learning rientation on assessed organizational capabilities. Industrial Marketing Management, Vol.31 (6): 545-554.

6. Chaffee, E. 1995. "Three models of strategy", Academy of Management Review, vol 10, no. 1, Chakrabarty, S. 2009. The Influence of National Culture and Institutional Voids on Family Ownership of Large Firms: A Country Level Empirical Study. Journal of International Management, Vol: 15(1)

7. Chrisman, J.J., Chua J.H. and Steier, L. 2003. An introduction to theories of family business, Journal of Business Venturing, 441-448.

8. Chua, J. H., Chrisman, J. J. and Sharma, P. 1999. Defining the family business by behavior. Entrepreneurship Theory \& Practice, Summer, 19-39.

9. David, F. 1989. Strategic Management, Columbus:Merrill Publishing Company, 1989

10. Donckels, R. and Freilich, E. 1991. Are family businesses really different? European experiences from Stratos. Family Business Review 4(2), 149-160.

11. Drucker, P. 1994. The Theory of the Business, Harvard Business Review, September-October, 39.

12. Fındıkçı, İ. 2008. Aile Şirketlerinde Yönetim ve Kurumsallaşma (3ncü basım). Alfa: İstanbul.

13. Flemons, D. G. and Cole, P. M. 1992. Connecting and separating family and business: A relational approach to consultation. Family Business Review, 5(3), 257-269.

14. Garvin, D. A. 1993. Building a Learning Organization. Harvard Business Review 71 (July-August), 78-91.

15. Gatignon, H. and Xuereb, J.M. 1997. Strategic orientations of the firm and new product performance, Journal of Marketing Research, Vol.34, 77-90.

16. Gebhardt, G.F., Carpenter, G.S. and Sherry Jr., J.F. 2006. Creating a Market Orientation: A Longitudinal, Multifirm, Grounded Analysis of Cultural Transformation, Journal of Marketing, Vol. 70, Pages 37-55. 
17. Gersick, K. E., Davis, J. A., McCollom H. M. and Lansberg, I. 1997. Generation to generation: Life cycles of the family business. Harvard Business School Press.

18. Gils, A.V., Voordeckers, W. and Heuvel, J.V.D., 2004. Environmentel Uncertainty and Strategic Behavior in Belgian Family Firms, European Management Journal, Vol:22, No:5, pages 588-595.

19. Habbershon T.G., Williams, M. and MacMillan I.C., 2003. A unified systems perspective of family firm performance, Journal of Business Venturing, 451-465.

20. Kırım A. 2002. Aile Şirketlerinin Yönetimi. İstanbul: Sistem Publications.

21. Lansberg, I. 1999. Succeeding Generations, Harvard Business School Press, Boston, MA.

22. Li, Y, Liu, Y. and Zhao, Y. 2006, The role of market and entrepreneurship orientation and internal control in the new product development activities of Chinese firms, Industrial Marketing Management. 35, 336-347.

23. Lumpkin, G. T., and Dess, G. G. 1996. Clarifying the entrepreneurial orientation construct and linking it to performance. Academy of Management Review, 21, 135-172.

24. Luecke, R., Katz R. 2003. Managing Creativity and Innovation. Harvard Business School Press.

25. Lynch, D.F., Keller, S.B. and Ozment, J. 2000. The effects of logistics capabilities and strategy on firm performance. Journal of Business Logistics, Vol. 21(2), 47-67.

26. Miller D., Breton-Miller I., Lester R. and Cannella A. 2007. Are family firms really superior performers? Journal of Corporate Finance, 1-30.

27. Narver, John C., Slater, S.F. \& Tietje, B. 1998. Creating a market orientation, Journal of Market-Focused Management, 2/3,Pages 241-256.

28. Naldi , L., Nordqvist, M., Sjoberg, K., Wiklund, J. 2007, "Entrepreneurial orientation, risk taking and performance in family firms, Family Business Review, 33-47.

29. Nunnally, J.C. 1978. Psychometric Theory (2nd Ed.). New York: McGraw Hill.

30. Nunnally, J. C. ve Bernstein, I. H. 1994. Psychometric Theory (3rd ed.). New York: McGraw-Hill

31. Pedler, M., Burgogyne, J. and Boydell, T. 1997. The Learning Company: A strategy for sustainable development. 2nd Ed. London; McGraw-Hill.

32. Pieper, T.M., Klein, S.B. 2007. The Bulleye: A systems approach to modeling family firms. Family Business Review. 20 (4): 301-319

33. Simpson P.M., Siguaw, J.A. and Enz, C.A. 2006, Innovation orientation outcomes: The good and the bad. Journal of Business Research, 1133-1141 .

34. Sinkula, J.M., Baker, W.E, Noordewier, T. 1997. A Framework for Market-Based Organizational Learning: Linking Values, Knowledge, and Behavior. Academy of Marketing Science. No:25, 305.

Learning, Entrepreneurship And Innovation Orientations In Turkish Family-Owned Firms 
35. Shanker, M.C., Astrachan, J.H. 1996. Myths and realities: family business's contribution to US economy A framework for assessing family business statistics, Family Business Review, 9-2, 107-123.

36. Sharma, P., Chrisman, J.J. and Chua, J.H. 1997. Strategic management of the family business: past research and future challenges. Family Business Review 10(1), pages 1-35.

37. Schulze,W.S., Lubatkin, M.H., Dino, R.N., \& Buchholtz, A.K., 2001. Agency relationship in family firms: theory and evidence, Organization Science, 12 (2), Pages 85-105.

38. Toni, A.D., Tonchia, S. 2001. Performance Measurement Systems: Models, Characteristics and Measures. International Journal of Operations\& Production Management, Vol:21, No:1/2 .

39. Totterdell P., Desmond L., Kamal B., Chris C., Toby W. 2002. An investigation on the contents and consequences of major organizational innovations. Int J Innov Magazine Vol:6, 3-68.

40. Trostel, A.O. and Nichols, M.I. 1982 Privately-held and publicly-held companies: a comparison of strategic choices and management processes. Academy of Management Journal 25, pages 47-62.

41. Westhead, P. 1997. Ambitions, External' environment and strategic factor differences between family and nonfamily companies. Entrepreneurship and Regional Development 9, 127-157.

42. Zahra, S.A., Neubaum, D.O. and El-Hagrassey, G.M. 2002. Competitive analysis and new venture performance: Understanding the impact of strategic uncertainty and venture origin. Entrepreneurship Theory and Practice, Vol.27(1), 1-28.

Learning, Entrepreneurship And Innovation Orientations In Turkish Family-Owned Firms 